Research Article

\title{
Anti-Müllerian Hormone Levels as Predictor of In Vitro Fertilization Outcomes
}

\author{
Mila Maidarti, ${ }^{1,2 *}$ Prini D. Garinasih, ${ }^{2}$ Aprilia A. Siregar, ${ }^{1,2}$ Gita Pratama, ${ }^{1,2}$ Achmad K. Harzif, ${ }^{1,2}$ \\ Kanadi Sumapraja, ${ }^{1,2}$ Budi Wiweko ${ }^{1,2}$
}

\author{
1Department of Obstetrics and Gynecology, ${ }^{2}$ Human Reproductive, Infertility and Family Planning \\ Research Center, Indonesia Medical Education and Research Institute (IMERI), \\ Faculty of Medicine Universitas Indonesia, Jakarta
}

${ }^{*}$ Corresponding author: milamaidarti@gmail.com

Received 30 February 2021; Accepted 27 July 2021 https://doi.org/10.23886/ejki.9.43.87

\begin{abstract}
A decrease in serum anti-müllerian hormone $(A M H)$ concentration suggests the reduction of antral follicle number. AMH serum level was correlated with ovarian stimulation outcomes, oocyte quantity and quality, embryo quality and in vitro fertilization (IVF) outcomes. However, the use of AMH to predict pregnancy rates in IVF is still debatable. This study aimed to determine the role of AMH in predicting ovarian response and pregnancy rates in IVF programs. This was a retrospective cohort study involving patients who underwent a short protocol of ovarian stimulation for IVF at the Yasmin clinic, dr Cipto Mangunkusumo General Hospital. from March 2013 to March 2021. A total of 1,527 out of 3,880 IVF cycles were included. Poor ovarian response was determined as a collection of fewer than four oocytes following ovarian stimulation. The data was then analyzed using the Mann Whitney test if the data distribution was not normal or the unpaired t-test if the data distribution was normal. Median AMH levels were higher in the normal (2.5(0.01-32)) compared to poor responder (0.68(0.01-6.86)) group ( $p<0.05$; Mann Whitney). Serum AMH level and age had predictive value for pregnancy rate $(p<0.05$; Mann Whitney).

Keywords: $A M H$, ovarian response, pregnancy rate, IVF.
\end{abstract}

\section{Kadar Hormon Anti-Müllerian sebagai Prediktor Luaran Fertilisasi in Vitro}

\begin{abstract}
Abstrak
Penurunan konsentrasi serum hormon anti-müllerian (HAM) menunjukkan penurunan jumlah folikel antral. HAM serum berkorelasi dengan luaran stimulasi ovarium kuantitas dan kualitas oosit serta kualitas embrio dan Iuaran fertilisasi in vitro (FIV). Namun, penggunaan HAM untuk memprediksi angka kehamilan dengan stimulasi ovarium pada FIV masih diperdebatkan. Tujuan penelitian ini untuk mengetahui peran serum HAM dalam memprediksi respons ovarium dan laju kehamilan pada program FIV. Penelitian ini adalah studi kohort retrospektif yang melibatkan pasien yang menjalani protokol singkat stimulasi ovarium pada program FIV di klinik Yasmin rumah sakit dr Cipto Mangunkusumo.dari bulan Maret 2013 sampai Maret 2021. Sebanyak 1.527 dari 3880 siklus IVF dimasukkan ke dalam penelitian. Dikatakan perespon buruk apabila diperoleh kurang dari empat oosit setelah stimulasi ovarium. Data kemudian dianalisis dengan menggunakan uji Mann Whitney bila sebaran data tidak normal atau uji t tidak berpasangan bila sebaran data normal. Median kadar HAM lebih tinggi pada kelompok perespons baik (2.5 (0.01-32)) dibandingkan perespons buruk (0.68 (0.01-6.86)) ( $p<0,05$; Mann Whitney). Kadar HAM serum dan usia memiliki nilai prediktif terhadap angka kehamilan ( $p<0,05$; Mann Whitney).
\end{abstract}

Kata kunci: hormon anti-Müllerian, respons ovarium, angka kehamilan, FIV. 


\section{Introduction}

Infertility has become a fairly frequent issue in the world. ${ }^{1}$ Along with the development of medical science, infertility therapy has become a means for couples who yearn for a child. One of the therapies is IVF, where several markers are used to determine the ovarian response to therapy, including follicle stimulating hormone (FSH), luteinizing hormone (LH), and estradiol (E2) levels accompanied by the ultrasound examination for antral follicle count. One of the latest, more accurate markers is AntiMüllerian Hormone (AMH). ${ }^{2}$

$\mathrm{AMH}$ is a glycoprotein of the transforming growth factor- $\beta$ (TGF- $\beta$ ) superfamily. It is generally accepted that $\mathrm{AMH}$ is expressed in a window of follicle growth and development from the secondary stage follicle. Its expression diminished once the follicles reach the size of more than $8-10 \mathrm{~mm}$ in diameter. ${ }^{3}$ Some studies using animal models have revealed that $\mathrm{AMH}$ inhibits primordial follicle initiation; thus it can protect the ovaries against ovarian aging by preventing the loss of primordial follicles. ${ }^{4,5}$ This can be adopted in a clinical setting to identify the quantity of primordial follicles as a high $\mathrm{AMH}$ level may reflect the degree of primordial follicle activation and the number of the follicles in the ovarian cortex. ${ }^{6}$

The $\mathrm{AMH}$ expression decreases gradually as follicles grow further and eventually becomes unnoticeable at a stage where gonadotropin dependent stage follicles initiate to grow. ${ }^{7}$ The AMH serum levels have been demonstrated to be highly correlated/related to the number of antral follicles and have seemed to be menstrual cycle independent with just minimal fluctuations during the cycles. ${ }^{8}$ This may reflect the constant growth and development of non-cyclic preantral and small antral follicles. Therefore/thus, its high inter-cycle reproducibility compared to other markers signifies that $\mathrm{AMH}$ constitutes a more consistent and strong marker for ovarian reserve. ${ }^{9}$ Since the quality and quantity of primordial follicles represent ovarian reserve, serum $\mathrm{AMH}$ level is used as a quantitative marker to predict the ovarian reserve and response. The ovarian reserve designates both the quantity and quality of oocytes and gradually declines with increasing age. ${ }^{2}$ It has been reported that $\mathrm{AMH}$ is a superior marker of the ovarian reserve than age alone and is better than other markers such as $\mathrm{FSH}, \mathrm{E2}$, and inhibin B. 7,10

Several studies have shown that $\mathrm{AMH}$ can accurately describe ovarian functions but cannot predict pregnancy. Pregnancy success can be due to other factors such as the quality of the sperm and oocytes and endometrial receptivity. ${ }^{11-13}$ Age is known to influence embryonic ploidy and live births in IVF. The older the age, the prognosis will be lower. ${ }^{14}$ However, other studies found an association between $\mathrm{AMH}$ and pregnancy success in IVF, although its predictive value is still uncertain. ${ }^{13,15} \mathrm{AMH}$ has emerged as a better predictor for controlled ovarian stimulation. In addition, $\mathrm{AMH}$ serum level has been revealed to be a suitable predictive marker for the poor ovarian response, cycle withdrawal and hyper-response to controlled ovarian stimulation. ${ }^{10}$ Nevertheless, its ability to foresee the other outcomes of IVF cycles, including the chances of becoming pregnant, remains controversial. ${ }^{10,16}$ This study aimed to determine whether basal AMH level is a good ovarian marker a good marker of ovarian response and clinical pregnancy rate in women undergoing ovarian stimulation for IVF.

\section{Methods}

\section{Study Subjects and Design}

A retrospective cohort study was designed to compare $\mathrm{AMH}$ values, $\mathrm{BMl}$ and age in patients who had completed at least one cycle of IVF from March 2013 to March 2021 in the IVF Yasmin clinic, dr. Cipto Mangunkusumo General Hospital. For those who had multiple IVF cycles, data from the first cycle completed were obtained. We included the data from patients who had undergone ovarian stimulation and had complete data of $\mathrm{AMH}$ and IVF outcomes in term of patient characteristics, the type and duration of stimulation, the oocytes number, fertilization rate and pregnancy rate. Cycles were omitted if they did not incorporate a treatment outcome, did not go for embryo transfer, were scheduling preimplantation genetic testing for aneuploidy, and exhibited multiple cycles start within our dataset. The data were retrospectively analysed. Secondary outcomes of interest contained background characteristics of the study subjects, such as age, body mass index (BMI), infertility diagnosis, and cycle outcome data. We evaluated all initiated cycles during the study period. The same clinical and embryology team were involved in all treatments. As the consensus on the definition of poor ovarian response is not yet available. The most commonly used classification is based on the number of oocytes retrieved. Likewise, we used the same criteria. We outlined poor ovarian response as a collection of fewer than four oocytes at oocytes retrieval. 


\section{Ovarian stimulation Protocol}

All patients underwentantagonist, or shortprotocol for ovarian stimulation involving gonadotrophin stimulation started from day 2 or 3 of the cycle. $\mathrm{GnRH}$ antagonist (Cetrotide; Serono International, Switzerland) $0.25 \mathrm{mg} /$ day was given when the leading follicle achieved a diameter of $14 \mathrm{~mm}$. Ovarian response was evaluated at 2- to 3-day intervals using vaginal sonography. Recombinant human chorionic gonadotropin ( $\mathrm{hCG}$ ) was administered when at least three lead follicles reached $17 \mathrm{~mm}$. Vaginal progesterone was administered in combination with oral dydrogesterone as luteal phase support.

The patients were analysed in groups based on their leading cause of infertility: tubal factor, male factor, unexplained infertility, anovulatory dysfunction, endometriosis and diminished ovarian response. The endpoints were the pregnancy rate, fertilization and cleavage rate, days of stimulation, and total gonadotropin dose. Clinical pregnancy was defined as an intrauterine gestational sac noticed by first trimester transvaginal ultrasound examination.

\section{Statistical Analysis}

Statistical analysis was performed with the SPSS 20 package. We used student's t-test to analyses the normally distributed continuous variables. While the Mann Whitney test was used to assess the data that was not normally distributed. Chi-square or Fisher's exact tests were used for categorical data, $p$-values $<0.05$ were considered to be statistically significant. Normally distributed data are presented as mean $\pm S D$, while median and range are used to present the not normally distributed data.

\section{Results \\ Demographic Characteristics of the Subjects}

A total of 1,527 IVF/ICSI cycles were included in this study. The most common cause of infertility in normal responders was a male factor (29.3\%), while in poor responders was tubal factor $(95.8 \%)$. The age of the study subjects in normal responders was tended to be younger than those in poor responder group $(p<0.001)$. In addition, the duration of infertility was significantly longer in poor responder group compared to normal responders $(p=0.001)$. BMI and AMH serum levels in normal responders did not differ from that in the poor responder group $(p>0.05)$ (Table 1$)$.

\section{IVF Outcomes Based on Ovarian Response}

The normal responders had a higher number of oocytes retrieved and inseminated $(p<0.05)$, with a lower fertilization rate than in poor responders $(p<0.001)$. The cleavage rate was higher in normal responders, who also had higher biochemical and clinical pregnancy rates than poor responders ( $81 \%$ vs $19 \% ; 87.6 \%$ vs $12.4 \%$, respectively). These variables were significantly associated with ovarian response $(p<0.05)$, while initial and total recombinant $\mathrm{FSH}$ dose, together with the duration of stimulation, were not statistically significant $(p>0.05)$ (Table 2).

Table 1. Ovarian Responders Based on Demographic Characteristics of the Subjects

\begin{tabular}{lccc}
\hline \multicolumn{1}{c}{ Characteristics } & Normal Responders & Poor Responders & p value \\
\hline Age; median, range & $35(22-48)$ & $38(25-50)$ & $<0.001$ \\
Duration of infertility; years & $6(4-23)$ & $7(1-25)$ & 0.001 \\
BMI; mean \pm SE & $24.2 \pm 0.13$ & $23.9 \pm 0.2$ & 0.573 \\
AMH level; median, range & $2.5(0.01-32)$ & $0.68(0.01-6.86)$ & $<0.001$ \\
Number of patients with primary infertility; $\mathrm{n}, \%$ & $991(71.9)$ & $387(28.1)$ & 0.120 \\
Number of patients with secondary infertility; $\mathrm{n}, \%$ & $95(66.9)$ & $47(33.1)$ & $<0.001$ \\
Cause of infertility; $\mathrm{n}, \%$ & & & \\
Endometriosis & $134(12.3)$ & $32(38)$ & $3(0.7)$ \\
$\quad$ Anovulatory dysfunction & $154(14.2)$ & $57(13.1)$ & $25(95.8)$ \\
Male factor & $318(29.3)$ & $32(7.4)$ & $235(59.9)$ \\
Tubal factor & $111(10.2)$ & $212(19.5)$ & \\
$\quad$ Unexplained infertility & $157(14.5)$ & & \\
Diminished ovarian reserve & & & \\
\hline
\end{tabular}


Table 2. IVF Outcomes Based on Ovarian Response

\begin{tabular}{lccc}
\hline Outcomes & Normal Responders & Poor Responders & p value \\
\hline Initial recombinant FSH dose (median; range) & $300(75-465)$ & $300(50-465)$ & 0.364 \\
Total recombinant FSH dose (median; range) & $3075(300-10.650)$ & $3300(375-8400)$ & 0.152 \\
Duration of stimulation & $11(4-27)$ & $11(5-26)$ & 0.355 \\
Number of oocytes retrieved (median; range) & $9(3-47)$ & $2(0-4)$ & $<0.001$ \\
Number of inseminated oocytes (median; range) & $7(0-41)$ & $2(0-4)$ & $<0.001$ \\
Fertilization rate & $70(0-100)$ & $100(0-100)$ & $<0.001$ \\
Cleavage rate (mean \pm SE) & $97.3 \pm 0.42$ & $68.6 \pm 2.23$ & $<0.001$ \\
Biochemical pregnancy rate (\%) & 81 & 19 & $<0.001$ \\
Clinical pregnancy rate (\%) & 87.6 & 12.4 & $<0.001$ \\
\hline
\end{tabular}

\section{Correlation between AMH Serum Level, Age, $B M I$ and IVF outcomes}

The AMH serum level was significantly correlated with cleavage rate $(r=0.251, p<0.05)$ and the number of oocytes retrieved $(r=0.705, p<0.05)$. Meanwhile, serum AMH level was negatively correlated with age, duration of stimulation, initial and total recombinant FSH dose $(p<0.05)$. The duration of stimulation had the strongest negative correlation $(r=-0.79)$. No correlation was identified between serum AMH level and BMI, inseminated oocytes, and fertilization rate $(p>0.05)$ (Table 3$)$.

Table 3. Correlation between Subject Characteristics and IVF Outcomes

\begin{tabular}{lcc}
\hline Characteristics & $\mathbf{r}$ & $\mathbf{p}$ value \\
\hline BMI & 0.002 & 0.937 \\
Age & -0.318 & $<0.001$ \\
Oocyte number & 0.705 & $<0.001$ \\
Inseminated oocytes & 0.686 & 0.086 \\
Fertilisation rate & -0.12 & 0.649 \\
Cleavage rate & 0.251 & $<0.001$ \\
Duration of stimulation & -0.79 & 0.002 \\
Initial recombinant FSH dose & -0.346 & $<0.001$ \\
Total recombinant FSH dose & -0.219 & $<0.001$ \\
\hline
\end{tabular}

\section{AMH as A Predictor of Pregnancy Rate}

The median serum AMH levels were significantly lower in negative biochemical and clinical pregnancy groups compared to the groups with positive for both biochemical and clinical pregnancies $(p>0.05)$. The study subjects in the group with positive for biochemical and clinical pregnancy rates were younger compared to those in the opposite groups. Serum AMH level and patient age had a predictive value for pregnancy rate $(p<0.05)($ Table 4$)$.

Table 4. Pregnancy Rate Based on AMH Level and Age

\begin{tabular}{lcc}
\hline Pregnancy rate & AMH serum level & Age \\
\hline Biochemical pregnancy $(+)$ & $1.89(0.01-21.84)$ & $35(23-47)$ \\
Biochemical pregnancy $(-)$ & $1.44(0.01-32.0)$ & $37(22-50)$ \\
p value & 0.003 & 0.05 \\
Clinical pregnancy $(+)$ & $2.3(0.09-16.4)$ & $1.48(0.01-32)$ \\
Clinical pregnancy $(-)$ & $34(24-46)$ & $37(22-50)$ \\
p value & 0.009 & $<0.001$ \\
\hline
\end{tabular}




\section{Discussions}

Infertility is an issue that is often experienced by couples of childbearing ages, where various treatments have emerged, one of which is IVF. This study aimed to determine whether the basal AMH level is a good marker in determining ovarian response and clinical pregnancy rate in women who experience ovarian stimulation in IVF. We demonstrated a significant positive relationship occurs between IVF clinical pregnancy rate and the quantitative ovarian reserve as measured by the serum AMH. Nevertheless, the power of this association is also influenced by the patient's age. The results found in this study are consistent with the research by Gomez et $\mathrm{al}^{17}$, who found a negative correlation between $\mathrm{AMH}$ levels with age and recombinant FSH dose and a positive correlation with oocyte count. ${ }^{17} \mathrm{AMH}$ levels are positively associated with fertility rates in women aged $30-42$ years. ${ }^{18} \mathrm{AMH}$ can be found in follicles that have experience recruitment and have not been selected for dominance. In this context, $\mathrm{AMH}$ is thought to have an important role in follicular growth and selection for ovulation. ${ }^{19}$ Serum AMH levels are also directly proportional to the number of follicles that develop. Along with the increase in the number of oocytes, the serum AMH level will be higher. ${ }^{2,3}$ More oocytes means the possibility of getting quality embryos is greater so that the IVF success rate will increase. ${ }^{20}$

It has been shown recently that a number of factors, either alone or in combination, have been utilized as predictive value for IVF outcomes, but the success rate is limited. An attempt to postpone conceiving, either with natural conception or IVF, does not only decrease a woman's tailored chances of success but this may be attributed to the decreased in overall and age-based success rates. ${ }^{21}$ The $\mathrm{AMH}$ level was positively related to the number of oocytes collected either in young or older patients, which is accordance with the outcomes of a previous study. ${ }^{22}$ Hence, it is possible that $\mathrm{AMH}$ may also be related to the quality of oocyte yield. ${ }^{12}$, ${ }^{23}$ Similarly, Brodin et $\mathrm{al}^{24}$ found that $\mathrm{AMH}$ levels reflect the quality of the ovarian reserve regardless of quantity. Higher AMH levels can have more euploid oocytes than lower AMH levels. ${ }^{24} \mathrm{AMH}$ was independently associated with pregnancy and live birth rates. ${ }^{24}$ In line with the findings in the present study, several large-scale retrospective analyses have indicated an association concerning $\mathrm{AMH}$ and pregnancy rates following ovarian stimulation for IVF. ${ }^{23,25}$ This may be due to the tailored ovarian stimulation protocol based on the AMH levels. ${ }^{23}$

Age is also known to have a predictive value of pregnancy. Females in their thirties will experience a decline in fertility. The decline in fertility is directly proportional to age. Spontaneous pregnancy begins to decline at the age of 31-35 years. This is thought to be related to genetic factors on the autosome and $\mathrm{X}$ chromosome and other factors such as decreased oocyte quality, diminished ovarian reserve, lower incidence of embryo implantation, and hormonal changes. Ovarian reserve is reduced to only 25,000 oocytes remaining at 37 years of age.$^{26}$ Decreased oocyte quality is associated with the formation of reactive oxygen species (ROS) and mitochondrial DNA disorders with age. ${ }^{20} \mathrm{AMH}$ levels are also related to age, which will be positively related until the age of 16 years, then will decrease starting at the age of 25 years until menopause. ${ }^{2}$

Variations in $\mathrm{AMH}$ levels can be different both inter-individual and intra-individual. Differences in $\mathrm{AMH}$ levels between individuals due to differences in follicular activity and the number of follicles of each individual. $\mathrm{AMH}$ levels were also found to be lower in African, Hispanic, Chinese, and Southeast Asian races, so that ethnicity could be one of the causes of variations in $\mathrm{AMH}$ levels. While differences in intra-individual $\mathrm{AMH}$ levels can be caused by age, where ages less than 38 years can have variations in AMH levels up to $>0.5 \mathrm{ng} /$ $\mathrm{ml}$. AMH levels also follow a circadian rhythm, with the lowest levels at 4 to 6 in the morning. ${ }^{27}$

The $\mathrm{AMH}$ serum level was significantly lower in the poor responder group. Likewise, most of the causes of infertility in the poor responder group were diminished ovarian reserve. It has been reported that patients with tremendously low ovarian reserve still display reasonable live birth rates, and low $\mathrm{AMH}$ levels alone do not signify a suitable indicator for withholding treatment for infertility. ${ }^{28}$ It is interesting to note that the initial and total dose of recombinant $\mathrm{FSH}$ was tended to be similar across the groups meaning that in our case, $\mathrm{AMH}$ is not a good predictor to determine the initial and total dose of recombinant FSH. In contrast, A number of studies have confirmed the effectiveness of $\mathrm{AMH}$ in determining the initial dose of gonadotropins in order to amplify response while lowering the risk of ovarian hyperstimulation syndrome. ${ }^{29}$

We included a large number of patients who were enrolled on the IVF program. It is worth considering the broader significance of the findings in the present study because this can be used as a base to provide counselling for patients with inadequate responses to ovarian stimulation. Patients who are predicted to have insufficient response to ovarian stimulation due to low AMH serum levels may be advised with regard to the low probability of attaining successful pregnancy. This 
is exclusively beneficial in countries where IVF is not covered by national health insurance. Moreover, it is very important for patients to recognize their chances of a successful pregnancy before ensuing the IVF. For younger patients with low AMH levels, even if only a few oocytes were retrieved during the collection, the possibility of getting pregnant is judicious. In this context, it is likely that the young patients were eager to proceed with IVF after obtaining counseling that though the outcomes of the IVF program are not optimal, the chance would be equitable. Additionally, It is apparent that the routine practice of AMH screening in the poor responder subgroup of patients may enhance the results of IVF and prevent a number of patients who preferred not to try IVF. ${ }^{30}$ Furthermore, in clinical settings, $\mathrm{AMH}$ can guide practitioners to select the finest treatment strategy and assign women with more realistic expectations before ovarian stimulation begins. $^{31}$

\section{Conclusion}

The serum level of $\mathrm{AMH}$ is a good predictor for determining ovarian reserve and response in IVF. Age and serum $\mathrm{AMH}$ levels can be predictors of pregnancy rates. The chances of getting pregnant are greater in patients with younger age and higher $\mathrm{AMH}$ levels. However, it should be noted that there are pronounced variations in $\mathrm{AMH}$ levels between individuals, so consideration is needed in measuring $\mathrm{AMH}$ levels and the use of additional markers to determine the success of pregnancy.

Serum AMH level helps clinicians to choose the optimal treatment strategy and to provide women with realistic expectations before treatment; however, AMH level are is a worse predictor of the chance of live birth. Different AMH assays have been developed, however, no international assay standard for measuring AMH exists, which is highly needed. AMH as a single measurement should not be used as a screening tool for natural fecundability in the general population, but longitudinal studies with repeated $\mathrm{AMH}$ values for the same women over time may be used to determine the rate of decline in $\mathrm{AMH}$ level and hence the primordial follicular depletion.

\section{References}

1. World Health Organization. Infertility: World Health Organization; 2020 [cited 2021 May 13]. Available from:https://www.who.int/news-room/fact-sheets/detail/ infertility.

2. Moolhuijsen LME, Visser JA. Anti-Mullerian Hormone and Ovarian Reserve: Update on Assessing Ovarian Function. J Clin Endocrinol Metab. 2020;105:3361-73. doi: 10.1210/clinem/dgaa513.
3. Jeppesen JV, Anderson RA, Kelsey TW, Christiansen SL, Kristensen SG, Jayaprakasan K, et al. Which follicles make the most anti-Mullerian hormone in humans? Evidence for an abrupt decline in AMH production at the time of follicle selection. Mol Hum Reprod. 2013;19:51927. doi: $10.1093 / \mathrm{molehr} /$ gat024.

4. Sonigo C, Beau I, Grynberg M, Binart N. AMH prevents primordial ovarian follicle loss and fertility alteration in cyclophosphamide-treated mice. FASEB J. 2019;33:1278-87. doi: 10.1096/fj.201801089R.

5. Bertoldo MJ, Walters KA, Ledger WL, Gilchrist RB, Mermillod P, Locatelli Y. In-vitro regulation of primordial follicle activation: challenges for fertility preservation strategies. Reprod Biomed Online. 2018;36:491-9. doi: 10.1016/j.rbmo.2018.01.014.

6. Sonigo C, Beau I, Binart N, Grynberg M. AntiMüllerian Hormone in Fertility Preservation: Clinical and Therapeutic Applications. Clin Med Insights Reprod Health. 2019;13:1179558119854755. doi: 10.1177/1179558119854755.

7. La Marca A, Nelson SM, Sighinolfi G, Manno M, Baraldi E, Roli L, et al. Anti-Müllerian hormone-based prediction model for a live birth in assisted reproduction. Reprod Biomed Online. 2011;22:341-9. doi: 10.1016/j.rbmo.2010.11.005.

8. Iwase A, Nakamura T, Osuka S, Takikawa S, Goto M, Kikkawa F. Anti-Müllerian hormone as a marker of ovarian reserve: What have we learned, and what should we know? Reprod Med Biol. 2016;15:127-36. doi: 10.1007/s12522-015-0227-3.

9. Jiao X, Meng T, Zhai Y, Zhao L, Luo W, Liu P, et al. Ovarian Reserve Markers in Premature Ovarian Insufficiency: Within Different Clinical Stages and Different Etiologies. Front Endocrinol. 2021;12:601752. doi: 10.3389/fendo.2021.601752.

10. Anckaert E, Smitz J, Schiettecatte J, Klein BM, Arce JC. The value of anti-Mullerian hormone measurement in the long $\mathrm{GnRH}$ agonist protocol: association with ovarian response and gonadotrophin-dose adjustments. Hum Reprod. 2012;27:1829-39. doi: 10.1093/humrep/des101.

11. Umarsingh S, Adam JK, Krishna SBN. The relationship between anti-Mullerian hormone (AMH) levels and pregnancy outcomes in patients undergoing assisted reproductive techniques (ART). PeerJ. 2020;8:e10390. doi: $10.7717 /$ peerj.10390.

12. Huang J, Lin J, Gao H, Wang Y, Zhu X, Lu X, et al. Antimüllerian Hormone for the Prediction of Ovarian Response in Progestin-Primed Ovarian Stimulation Protocol for IVF. Front Endocrinol. 2019;10:325. doi: 10.3389/fendo.2019.00325.

13. Tal R, Tal O, Seifer BJ, Seifer DB. Antimullerian hormone as predictor of implantation and clinical pregnancy after assisted conception: a systematic review and metaanalysis. Fertil Steril. 2015;103:119-30 e3. doi: 10.1016/j. fertnstert.2014.09.041.

14. Esteves SC, Alviggi C, Humaidan P, Fischer R, Andersen CY, Conforti A, et al. The POSEIDON Criteria and Its Measure of Success Through the Eyes of Clinicians and Embryologists. Front Endocrinol (Lausanne). 2019;10:814. doi: 10.3389/fendo.2019.00814. 
15. Yao L, Zhang W, Li H, Lin W. The role of serum AMH and $\mathrm{FF} A \mathrm{AM}$ in predicting pregnancy outcome in the fresh cycle of IVF/ICSI: a meta-analysis. Int J Clin Exp Med. 2015;8:1755-67.

16. Goswami M, Nikolaou D. Is AMH Level, Independent of Age, a Predictor of Live Birth in IVF? J Hum Reprod Sci. 2017;10:24-30. doi: 10.4103/jhrs.JHRS_86_16.

17. Gomez R, Schorsch M, Hahn T, Henke A, Hoffmann I, Seufert $\mathrm{R}$, et al. The influence of AMH on IVF success. Arch Gynecol Obstet. 2016;293:667-73. doi: 10.1007/ s00404-015-3901-0.

18. Steiner AZ, Herring AH, Kesner JS, Meadows JW, Stanczyk FZ, Hoberman S, et al. Antimullerian hormone as a predictor of natural fecundability in women aged 30-42 years. Obstet Gynecol. 2011;117:798-804. doi: 10.1097/AOG.0b013e3182116bc8.

19. Garg D, Tal R. The role of AMH in the pathophysiology of polycystic ovarian syndrome. Reprod Biomed Online. 2016;33:15-28. doi: 10.1016/j.rbmo.2016.04.007.

20. Zhang B, Meng Y, Jiang X, Liu C, Zhang H, Cui L, et al. IVF outcomes of women with discrepancies between age and serum anti-Müllerian hormone levels. Reprod Biol Endocrinol. 2019;17:58. doi: 10.1186/s12958-019-0498-3.

21. Choi B, Bosch E, Lannon BM, Leveille MC, Wong WH, Leader A, et al. Personalized prediction of first-cycle in vitro fertilization success. Fertil Steril. 2013;99:190511. doi: 10.1016/j.fertnstert.2013.02.016.

22. lliodromiti S, Anderson RA, Nelson SM. Technical and performance characteristics of anti-Müllerian hormone and antral follicle count as biomarkers of ovarian response. Hum Reprod Update. 2015;21:698-710. doi: 10.1093/humupd/dmu062.

23. Arce JC, La Marca A, Mirner Klein B, Nyboe Andersen A, Fleming R. Antimüllerian hormone in gonadotropin releasing-hormone antagonist cycles: prediction of ovarian response and cumulative treatment outcome in good-prognosis patients. Fertil Steril. 2013;99:1644-53. doi: 10.1016/j.fertnstert.2012.12.048.
24. Brodin T, Hadziosmanovic N, Berglund L, Olovsson M, Holte J. Antimüllerian hormone levels are strongly associated with livebirth rates after assisted reproduction. Journal Clin Endocrinol Metab. 2013;98:1107-14. doi: 10.1210/jc.2012-3676.

25. Tal R, Seifer DB, Wantman E, Baker V, Tal O.Antimüllerian hormone as a predictor of live birth following assisted reproduction: an analysis of 85,062 fresh and thawed cycles from the Society for Assisted Reproductive Technology Clinic Outcome Reporting System database for 2012-2013. Fertil Steril.. 2018;109:258-65. doi: 10.1016/j.fertnstert.2017.10.021.

26. Tan TY, Lau SK, Loh SF, Tan HH. Female ageing and reproductive outcome in assisted reproduction cycles. Singapore Med J. 2014;55:305-9. doi: 10.11622/ smedj.2014081.

27. Iliodromiti S, Anderson RA, Nelson SM. Technical and performance characteristics of anti-Müllerian hormone and antral follicle count as biomarkers of ovarian response. Hum Reprod Update. 2015;21:698-710. doi: 10.1093/humupd/dmu062.

28. Reichman DE, Goldschlag D, Rosenwaks Z. Value of antimüllerian hormone as a prognostic indicator of in vitro fertilization outcome. Fertil Steril.. 2014;101:1012-8.e1. doi: 10.1016/j.fertnstert.2013.12.039.

29. La Marca A, Papaleo E, Grisendi V, Argento C, Giulini S, Volpe A. Development of a nomogram based on markers of ovarian reserve for the individualisation of the folliclestimulating hormone starting dose in in vitro fertilisation cycles. BJOG. 2012;119:1171-9. doi: 10.1111/j.14710528.2012.03412.x

30. Baker VL, Gracia C, Glassner MJ, Schnell VL, Doody K, Coddington CC, et al. Multicenter evaluation of the Access $\mathrm{AMH}$ antimüllerian hormone assay for the prediction of antral follicle count and poor ovarian response to controlled ovarian stimulation. Fertil Steril. 2018;110:50613.e3. doi: 10.1016/j.fertnstert.2018.03.031.

31. Pilsgaard F, Grynnerup AG, Løssl K, Bungum L, Pinborg A. The use of anti-Müllerian hormone for controlled ovarian stimulation in assisted reproductive technology, fertility assessment and -counseling. Acta Obstet Gynecol Scand. 2018;97:1105-13. doi: 10.1111/aogs.13334. 